\title{
Pengaruh Tingkat Suku Bunga Dan Inflasi Terhadap Harga Saham Dengan Nilai Tukar Rupiah Sebagai Variabel Intervening Pada Jakarta Islamic Index (JII) Yang Terdaftar Di Bursa Efek Indonesia
}

\author{
Ayu Aizsa \\ Fakultas Ekonomi dan Bisnis \\ Universitas Palangka Raya, Indonesia \\ Solikah Nurwati \\ Program Magister Manajemen Pascasarjana \\ Universitas Palangka Raya, Indonesia \\ Luluk Tri Harinie \\ Program Magister Manajemen Pascasarjana \\ Universitas Palangka Raya, Indonesia \\ Email: ayuaizsaa@gmail.com
}

\begin{abstract}
Abstrak
Tujuan - penelitian bertujuan untuk membuktikan pengaruh nilai tukar rupiah sebagai mediasi hubungan antara suku bungan dan inflasi terhadar harga saham.

Desain/Methodologi/Pendekatan - Pengambilan sampel dilakukan dengan teknik purposive sampling. Sampel penelitian ini adalah 13 perusahaan yang tergabung dalam kelompok Jakarta Islamic Index. Analisis data yang digunakan adalah uji validitas dan uji reliabilitas dengan aplikasi smartPLS versi 3.

Temuan penelitian - Hasil penelitian menunjukkan bahwa: 1) tingkat suku bunga berpengaruh negatif dan signifikan terhadap harga saham; 2) inflasi berpengaruh negatif dan tidak signifikan terhadap harga saham; 3) nilai tukar rupiah berpengaruh positif dan signifikan terhadap harga saham; 4) tingkat suku bunga berpengaruh negatif dan signifikan terhadap nilai tukar rupiah; 5) inflasi berpengaruh negatif dan tidak signifikan terhadap nilai tukar rupiah; 6) nilai tukar rupiah tidak memediasi tingkat suku bunga terhadap harga saham; dan 7) nilai tukar rupiah tidak memediasi inflasi terhadap harga saham.
\end{abstract}

Kata kunci: tingkat suku bunga, inflasi, nilai tukar rupiah dan harga saham.

\section{The Effect Of Interest Rates And Inflation On Stock \\ Price By Using The Rupiah Exchange Rate As An Intervening Variable Of Jakarta Islamic Index (Jii) That Listed In Indonesia Stock Exchange}

\begin{abstract}
Research objectives: To prove the effect of the rupiah exchange rate as a mediation of the relationship between interest rates and inflation on stock prices. The samples in this research is 13 companies listed on Jakarta Islamic Index. Data analysis method used validity and reability test with the third version of smartPLS application. The results of this research indicate that: 1) interest rates influential negative and significant on stock price; 2) inflation influential negative and unsignificant on stock price; 3) Rupiah exchange rate influential positive and significant on stock price; 4) interest rate influential negative and significant on Rupiah exchange rate; 5) inflation influential negative and unsignificant on Rupiah exchange rate; 6) Rupiah exchange rate can not mediate interest rate on stock price; and 7) Rupiah exchange rate can not mediate inflation on stock price.
\end{abstract}

Keywords: interest rate, inflation, Rupiah exchange rate and stock price.

Jurnal Manajemen Sains dan Organisasi Vol 1, No 1, 2020 pp. $28-39$

FEB UPR Publishing $2685-4724$
Ayu Aizsa, Solikah Nurwati, and Luluk Tri Harinie. Published in the Jurnal Manajemen sains dan Organsasi. Published by FEB UPR Publishing Limited. This article is published under the Creative Commons Attribution (CC BY 4.0) licence. Anyone may reproduce, distribute, translate and create derivative works of this article (for both commercial and non-commercial purposes), subject to full attribution to the original publication and authors. 


\section{Pendahuluan}

Sebagai negara yang sedang berkembang, Indonesia membutuhkan adanya modal atau dana dalam jumlah yang besar sebanding dengan pertumbuhan yang telah ditargetkan. Dalam hal ini pasar modal dipandang sebagai sarana yang efektif untuk mempercepat pertumbuhan ekonomi suatu negara. Pasar modal dipandang sebagai salah satu sarana yang efektif dalam menghimpun dana jangka panjang. Tingkat pengembalian yang akan didapat berbanding lurus dengan resiko yang harus dihadapi, artinya semakin tinggi tingkat pengembalian semakin tinggi pula tingkat resikonya dan begitu pula sebaliknya. Investasi di pasar modal dewasa ini sangat dilirik oleh para investor. Sebelum melakukan investasi di pasar modal para investor mencari pertimbangan mengenai situasi pergerakan harga saham di pasar modal saat itu. Oleh karena itu para investor perlu mencari tahu apa saja yang mempengaruhi pergerakan harga saham. (Astuti, 2013). Terdapat beberapa indeks yang menjadi indikator dalam bursa efek, salah satunya adalah Jakarta Islamic Index (JII). Jakarta Islamic Index yang biasa disebut JII adalah salah satu indeks saham yang ada di Indonesia yang menghitung indeks harga rata-rata saham untuk jenis saham-saham yang memenuhi kriteria syariah. Dari data yang diperoleh, diketahui data rata-rata harga saham perusahaan berdasarkan penutupan harga saham periode tahun 2014-2018 yang diambil dari Jakarta Islamic Index adalah sebagai berikut:

Gambar 1 Grafik Pergerakan Rata-Rata Harga Saham Tahun 2014-2018

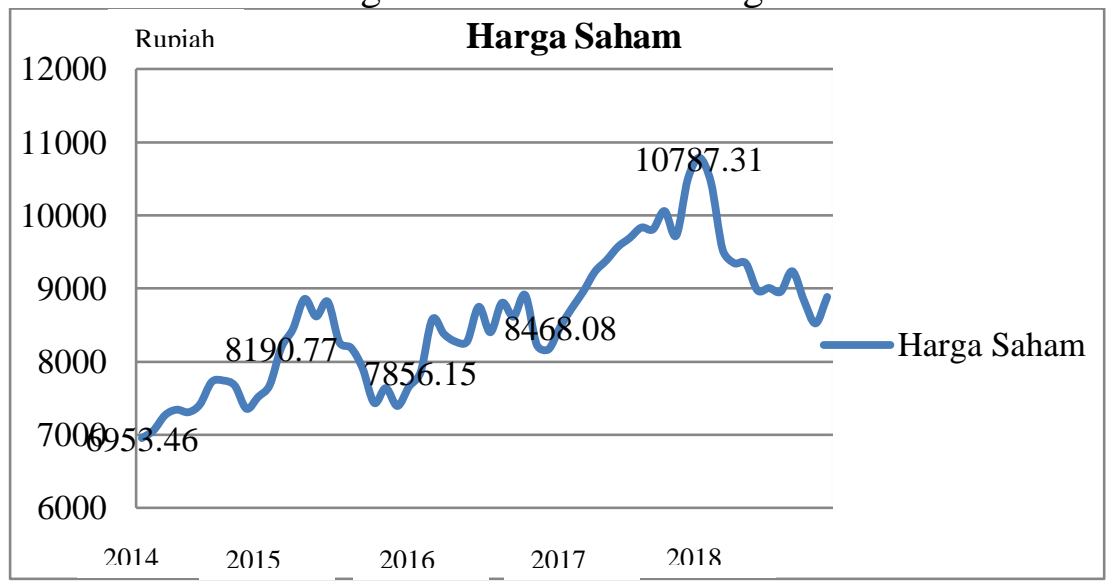

Sumber: Data diolah, 2019

Berdasarkan gambar 1.1 dapat dilihat bahwa harga saham perusahaan selama tahun 2014 sampai dengan 2018 mengalami fluktuasi. Pada tahun 2014 harga saham berada pada angka Rp6.953,46 dan mengalami peningkatan sebesar Rp1.237,31 di tahun 2015 menjadi Rp8.190,77 kemudian mengalami penurunan sebesar Rp334.62 menjadi Rp7.856,15 pada tahun 2016 dan pada tahun 2017 mengalami peningkatan sebesar Rp611,93 menjadi Rp8.468,08. Kemudian harga saham mengalami peningkatan kembali yang cukup tajam pada tahun 2018 sebesar Rp2.319,23 menjadi Rp10.787,31. Pergerakan harga saham dapat memberikan petunjuk tentang peningkatan dan penurunan aktivitas pasar modal dalam melakukan transaksi jual beli di perusahaan yang terdaftar di Jakarta Islamic Index. 
Dalam berinvestasi dalam bentuk saham seorang investor selalu memperhatikan faktor-faktor yang memengaruhi harga saham yang akan dibelinya. Faktor lingkungan sosial dan ekonomi seperti tingkat inflasi dan suku bunga, perkembangan kurs, kebijakan moneter, neraca pembayaran dan APBD, kondisi ekonomi dan keadaan politik. Tingkat suku bunga merupakan salah satu faktor yang memengaruhi harga saham. Tingkat suku bunga yang meningkat akan meningkatkan suku bunga yang diisyaratkan atas investasi pada suatu saham. Di samping itu, tingkat suku bunga yang meningkat bisa juga menyebabkan investor menarik investasinya pada saham dan memindahkannya pada investasi berupa tabungan ataupun deposito. (Kewal, 2012).

Tingkat inflasi juga merupakan salah satu variabel yang dapat memengaruhi harga saham. Inflasi merupakan indikator ekonomi yang menyebabkan kenaikan harga barang dan jasa dalam suatu periode. Adanya inflasi yang tinggi akan menyebabkan naiknya biaya produksi. Tingkat inflasi adalah prosentase kenaikan tahunan dalam tingkat harga umum yang diukur berdasarkan indeks harga konsumen. Dengan adanya inflasi maka harga barang mengalami peningkatan, sehingga daya beli masyarakat akan menurun. Hal ini akan menurunkan minat investor untuk melakukan investasi dan akan terjadi penurunan terhadap harga saham perusahaan (Nofiatin, 2013).

Terdapat alternatif investasi lain yang juga dapat memengaruhi transaksi saham di bursa efek, yakni investasi pada valuta asing dalam hal ini adalah nilai tukar rupiah atas dollar (USD). Nilai tukar atau kurs secara sederhana dapat di artikan sebagai harga mata uang suatu negara terhadap mata uang asing. Jika saat nilai tukar dollar sedang melemah terhadap rupiah dan dapat diprediksikan akan kembali menguat di masa mendatang dan juga ketika alternatif investasi lain dirasa kurang menjanjikan, maka investor mungkin cenderung akan menginvestasikan dananya ke dalam bentuk mata uang dollar dengan harapan memperoleh gain dari selisih kurs. Kondisi tersebut pada akhirnya akan berdampak pada aktivitas pasar modal dan selanjutnya akan berakibat pada pergerakan harga saham di BEI.

Penelitian yang dilakukan Ampeningrum (2005) menunjukkan bahwa tingkat suku bunga dan inflasi tidak berpengaruh terhadap harga saham. Namun, dalam penelitian lain yang dilakukan oleh Aprilia (2017) menunjukkan hasil yang berbeda yaitu tingkat suku bunga dan inflasi berpengaruh terhadap harga saham. Penelitian yang dilakukan oleh Ginting (2016) menunjukkan bahwa nilai tukar berpengaruh signifikan terhadap harga saham. Sedangkan, dalam penelitian yang dilakukan oleh Jayanti (2014) menunjukkan bahwa nilai tukar berpengaruh negatif signifikan terhadap harga saham. Beberapa penelitian juga menunjukkan bahwa tingkat suku bunga dan inflasi berpengaruh terhadap nilai tukar rupiah. Hal ini didukung oleh penelitian yang dilakukan Khajjah (2015) yang menunjukkan bahwa tingkat suku bunga berpengaruh negatif signifikan dan inflasi berpengaruh positif signifikan terhadap nilai tukar rupiah. Namun pada penelitian yang dilakukan Musyaffa' (2017) menunjukkan hasil yang berbeda yaitu tingkat suku bunga berpengaruh positif signifikan dan inflasi berpengaruh negatif tidak signifikan terhadap nilai tukar rupiah.

Penelitian yang akan dilakukan menyangkut permasalahan tentang hubungan tingkat suku bunga dan inflasi terhadap harga saham serta hubungan tingkat suku bunga dan inflasi terhadap harga saham melalui nilai tukar rupiah sebagai variabel intervening. Nilai tukar rupiah sebagai variabel intervening karena beberapa penelitian sebelumnya telah menunjukkan adanya research gap (kesenjangan) bahwa tingkat suku bunga, inflasi, 
dan nilai tukar rupiah berpengaruh terhadap harga saham, namun tingkat suku bunga dan inflasi juga berpengaruh terhadap nilai tukar rupiah. Hal ini membuat peneliti ingin mengetahui apakah tingkat suku bunga dan inflasi juga mempengaruhi harga saham melalui nilai tukar rupiah sebagai variabel intervening.

Menurut Tandeilin (2001) dalam Jayanti (2014), hubungan antara tingkat suku bunga dengan harga saham yaitu, perubahan suku bunga akan mempengaruhi harga saham secara terbalik, ceteris paribus. Artinya, jika suku bunga meningkat, maka harga saham akan turun, dan sebaliknya. Jika suku bunga naik, maka return investasi yang terkait dengan suku bunga juga naik. Kondisi seperti ini bisa menarik minat investor yang sebelumnya berinvestasi di saham untuk memindahkan dananya dari saham ke deposito dan tabungan. Jika sebagian besar investor melakukan tindakan yang sama yaitu banyak investor yang menjual saham, maka harga saham akan turun.

H1: Tingkat suku bunga berpengaruh terhadap harga saham di Jakarta Islamic Index

(JII) yang terdaftar di Bursa Efek Indonesia

Samsul (2006) dalam Efni (2009) menyimpulkan bahwa inflasi yang tinggi akan menjatuhkan harga saham di pasar. Peningkatan inflasi secara relatif berpengaruh negatif terhadap harga saham. Inflasi meningkatkan pendapatan dan biaya perusahaan. Jika peningkatan biaya produksi lebih tinggi dari peningkatan harga yang dapat dinikmati oleh perusahaan maka profitabilitas perusahaan akan turun. Jika profit yang diperoleh perusahaan kecil, hal ini akan mengakibatkan para investor tidak ingin menanamkan dananya di perusahaan tersebut sehingga harga saham menurun.

H2: Inflasi berpengaruh terhadap harga saham di Jakarta Islamic Index (JII) yang terdaftar di Bursa Efek Indonesia

Madura (2000) dalam Efni (2009) menjelaskan perubahan nilai tukar mempunyai pengaruh negatif terhadap harga saham. Artinya apabila nilai mata uang asing naik maka harga saham akan turun, hal disebabkan harga mata uang asing yang tinggi perdagangan di BEI akan semakin lesu, karena tingginya nilai mata uang mendorong investor berinvestasi di pasar uang. Dan sebaliknya apabila nilai mata uang asing turun terhadap mata uang dalam negeri maka maka harga saham akan naik disebabkan turunnya mata uang mendorong investor untuk berinvestasi di pasar modal.

H3: Nilai tukar rupiah berpengaruh terhadap harga saham di Jakarta Islamic Index

(JII) yang terdaftar di Bursa Efek Indonesia

Perubahan suku bunga relatif mempengaruhi investasi dalam sekuritas-sekuritas asing, yang selanjutnya akan mempengaruhi permintaan dan penawaran valuta asing. Hal ini akan mempengaruhi pula kepada nilai tukar mata uang. Menurut Frederic S. Mishkin (2008) dalam Kirana (2017) perubahan dalam suku bunga domestik seringkali menjadi faktor umum yang mempengaruhi nilai tukar. Ketika suku bunga riil domestik mengalami kenaikan, maka mata uang domestik mengalami apresiasi. Sebaliknya ketika suku bunga domestik mengalami kenaikan menuju perkembangan inflasi yang diharapkan makka mata uang domestik akan terdepresiasi.

H4: Tingkat suku bunga berpengaruh terhadap nilai tukar rupiah

Madura (2009) dalam Khajjah (2015) menjelaskan perubahan dalam laju inflasi 
dapat mempengaruhi aktifitas perdagangan internasional. Jika inflasi suatu negara meningkat, permintaan atas mata uang negara tersebut menurun dikarenakan ekspornya juga turun (disebabkan harga yang lebih tinggi). Selain itu, konsumen dan perusahaan dalam negara tersebut cenderung meningkatkan impor mereka. Kedua hal tersebut akan menekan inflasi yang tinggi pada mata uang suatu negara. Tingkat inflasi antarnegara berbeda, sehingga pola perdagangan internasional dan nilai tukar akan berubah sesuai dengan inflasi tersebut.

H5: Inflasi berpengaruh terhadap nilai tukar rupiah

Menurut Cahyono (2010) dalam Wahyuningsih (2018), kenaikan suku bunga akan meningkatkan beban bunga emiten, sehingga labanya bisa terpangkas. Selain itu, ketika suku bunga tinggi, biaya produksi akan meningkat dan harga produk akan lebih mahal sehingga konsumen mungkin akan menunda pembeliannya dan menyimpan dananya di bank. Akibatnya penjualan perusahaan menurun. Penurunan penjualan perusahaan dan laba akan menelan harga saham. Perubahan suku bunga relatif mempengaruhi investasi dalam sekuritas-sekuritas asing, yang selanjutnya akan mempengaruhi permintaan dan penawaran valuta asing. Hal ini akan mempengaruhi pula kepada nilai tukar mata uang. Suku bunga turun akan mengurangi minat investor untuk memegang rupiah karena insentif yang diterima menurun sehingga nilai tukar rupiah akan melemah (Wahyuningsih, 2018).

H6: Tingkat suku bunga berpengaruh terhadap harga saham melalui nilai tukar rupiah di Jakarta Islamic Index (JII) yang terdaftar di Bursa Efek Indonesia

Inflasi merupakan kenaikan harga barang dan jasa yang mempunyai pengaruh luas demikian juga terhadap harga saham di pasar modal. Dengan inflasi maka akan terjadi naik turunnya harga saham. Inflasi erat kaitannya dengan nilai tukar mata uang. Perubahan tingkat inflasi dapat mempengaruhi permintaan mata uang di suatu negara, sehingga dapat pula mempengaruhi pola perdagangan internasional (Wahyuningsih, 2018).

H7: Inflasi berpengaruh terhadap harga saham melalui nilai tukar rupiah di Jakarta Islamic Index (JII) yang terdaftar di Bursa Efek Indonesia

Gambar 2

Kerangka Konseptual

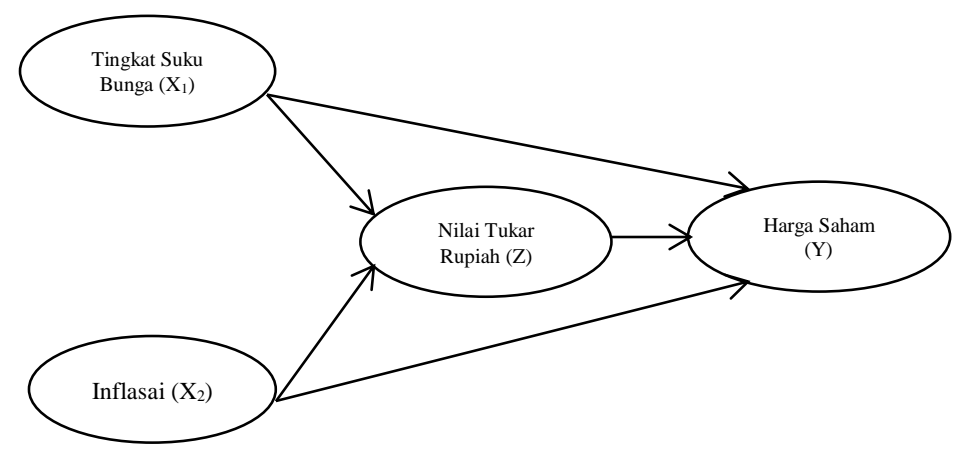

Sumber: Dikembangkan peniliti 


\section{Metode Penelitian}

Penelitian ini merupakan penelitian deskriptif-kuantitatif. Sumber data yang digunakan untuk penelitian ini diperoleh dari situs resmi Bursa Efek Indonesia (BEI) yaitu www.idx.co.id, situs resmi Badan Pusat Statistik yaitu www.bps.go.id dan situs resmi Bank Indonesia yaitu www.bi.go.id selama periode tahun 2014-2018. Sampel dalam penelitian ini berjumlah 13 perusahaan di Jakarta Islamic Index (JII) yang dipilih dengan purposive sampling.

Variabel dan indikator yang digunakan dalam penelitian ini dapat dilihat dalam tabel berikut ini:

Tabel 1. Identifikasi Variabel

\begin{tabular}{lll}
\hline \multicolumn{1}{c}{ Variabel } & \multicolumn{1}{c}{ Definisi } & Indikator Variabel \\
\hline Tingkat Suku Bunga & $\begin{array}{l}\text { BI Rate adalah tingkat suku bunga jangka pendek } \\
\text { dengan tenor satu bulan yang ditetapkan dan }\end{array}$ & \\
& $\begin{array}{l}\text { diumumkan oleh Bank Indonesia (BI) secara } \\
\text { periodik yang berfungsi sebagai sinyal kebijakan } \\
\text { moneter. }\end{array}$ & \\
\hline Inflasi (X2) & $\begin{array}{l}\text { Inflasi yaitu kecenderungan dari harga-harga Inflasi } \\
\text { untuk menaik secara terus-menerus. }\end{array}$ & \\
& & \\
\hline Nilai Tukar Rupiah (Z) & $\begin{array}{l}\text { Nilai tukar rupiah adalah mengukur kurs mata Nilai tukar } \\
\text { uang rupiah dalam satuan valuta asing. }\end{array}$ & \\
\hline Harga Saham (Y) & $\begin{array}{l}\text { Harga saham adalah harga suatu saham yang Harga saham } \\
\text { terjadi di pasar bursa pada saat tertentu yang } \\
\text { ditentukan oleh pelaku pasar dan ditentukan oleh }\end{array}$ & \\
permintaan dan penawaran saham yang & \\
bersangkutan di pasar modal. & \\
\hline
\end{tabular}

Sumber: Data sekunder dikembangkan, 2019

Data analisis menggunakan Partial Least Square (PLS) yang merupakan metode analisis data yang bersifat soft modeling karena dapat digunakan untuk semua skala data dan tidak memerlukan banyak asumsi.

\section{Hasil dan Pembahasan}

\section{Evaluasi Model Pengukuran (outer model)}

Tabel 2

Uji Validitas Konvergen dengan Loading Factor

\begin{tabular}{llcc}
\hline \multicolumn{1}{c}{ Variabel } & \multicolumn{1}{c}{ Indikator } & Loading Factor & Keterangan \\
\hline Tingkat Suku Bunga & Suku Bunga & 1,000 & Valid \\
\hline Inflasi & Inflasi & 1,000 & Valid \\
\hline Nilai Tukar Rupiah & Nilai Tukar & 1,000 & Valid \\
\hline Harga Saham & Harga Saham & 1,000 & Valid \\
\hline
\end{tabular}

Sumber: Data Diolah, 2019 
Berdasarkan tabel 3 nilai loading factor yang dihasilkan dapat diketahui bahwa semua indikator masing-masing variabel baik tingkat suku bunga, inflasi, nilai tukar rupiah, dan harga saham memiliki nilai loading factor yang lebih besar dari 0,5. Dengan demikian indikator tersebut dapat dinyatakan sebagari pengukur variabel latennya.

Tabel 3

Uji Validitas Diskriminan dengan AVE

\begin{tabular}{lccc}
\hline \multicolumn{1}{c}{ Variabel } & AVE & $\sqrt{ }$ AVE & Keterangan \\
\hline Tingkat Suku Bunga & 1,000 & 1,000 & Valid \\
\hline Inflasi & 1,000 & 1,000 & Valid \\
\hline Nilai Tukar Rupiah & 1,000 & 1,000 & Valid \\
\hline Harga Saham & 1,000 & 1,000 & Valid \\
\hline
\end{tabular}

Sumber: Data Diolah, 2019

Berdasarkan tabel 4 dapat dilihat bahwa nilai akar AVE yang dihasilkan dapat diketahui bahwa semua indikator masing-masing variabel yaitu tingkat suku bunga, inflasi, nilai tukar rupiah dan harga saham memiliki nilai akar AVE yang lebih besar dari 0,5. Dengan demikian indikator tersebut dapat dinyatakan valid sebagai pengukur variabel lainnya.

Tabel 4

Uji Reliabilitas dengan Composite Reliability dan Cronbach Alpha

\begin{tabular}{lccc}
\hline \multicolumn{1}{c}{ Variabel } & Composite Reliability & Cronbach Alpha & Keterangan \\
\hline Tingkat Suku Bunga & 1,000 & 1,000 & Reliabel \\
\hline Inflasi & 1,000 & 1,000 & Reliabel \\
\hline Nilai Tukar Rupiah & 1,000 & 1,000 & Reliabel \\
\hline Harga Saham & 1,000 & 1,000 & Reliabel \\
\hline
\end{tabular}

Sumber: Data Diolah, 2019

Berdasarkan tabel 5 dapat dilihat bahwa nilai composite reliability pada keempat variabel laten berada di atas 0,7 dan hasil evaluasi cronbach alpha di atas 0,6. Hal tersebut menunjukkan reliabilitas alat ukur yang tinggi, yakni pengukur dari masing-masing konstruk berkorelasi tinggi.

\section{Evaluasi Model Struktural (Inner Model)}

Tabel 5

Hasil Evaluasi Model Struktural dengan R Square

\begin{tabular}{lll}
\hline & R Square & R Square Adjusted \\
\hline Nilai Tukar Rupiah & 0,211 & 0,183 \\
\hline Harga Saham & 0,687 & 0,670 \\
\hline
\end{tabular}

Sumber: Data Diolah, 2019

Berdasarkan tabel 4.9 hasil pengujian menunjukkan nilai $\mathrm{R}^{2}$ untuk variabel nilai tukar rupiah sebesar 0,211. Nilai tersebut mengindikasikan bahwa variabel nilai tukar rupiah dapat dijelaskan oleh variabel tingkat suku bunga dan inflasi sebesar $21,1 \%$ sedangkan sisanya yaitu sebesar $78,9 \%$ dipengaruhi oleh variabel lain yang tidak terdapat dalam 
model penelitian. Sedangkan hasil pengujian menunjukkan nilai $\mathrm{R}^{2}$ untuk variabel harga saham sebesar 0,687. Nilai tersebut mengindikasikan bahwa variabel harga saham dapat dijelaskan oleh variabel tingkat suku bunga, inflasi, dan nilai tukar rupiah sebesar 68,7\% sedangkan sisanya yaitu sebesar $31,3 \%$ dipengaruhi oleh variabel lain yang tidak terdapat dalam model penelitian.

Gambar 3

Hasil Output PLS Algoritm

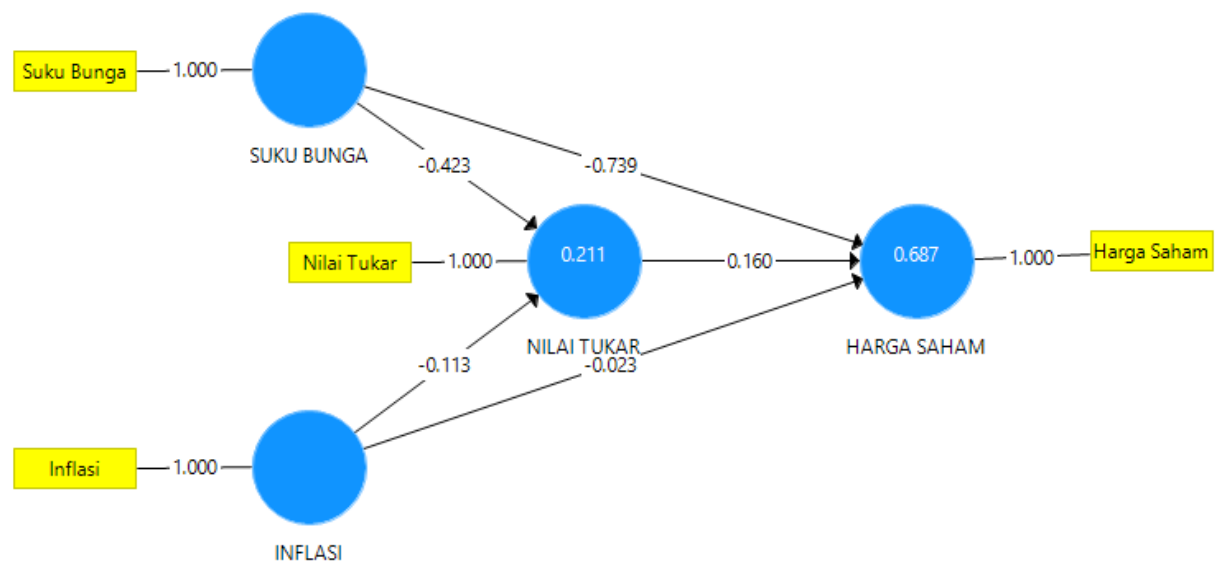

Sumber: Output PLS, 2019

Pada gambar 3 dapat dijelaskan bahwa bentuk bulat dicerminkan sebagai variabel dan bentuk kotak dicerminkan sebagai indikator. Pada penelitian ini, masing-masing variabel sama dengan indikatornya. Seperti variabel tingkat suku bunga dengan indikatornya suku bunga, diikuti dengan inflasi, nilai tukar dan harga saham. Kemudian juga dijelaskan antar hubungan langsung dan tidak langsung. Hubungan langsungnya adalah tingkat suku bunga dengan harga saham, inflasi dengan harga saham, nilai tukar rupiah dengan harga saham, tingkat suku bunga dengan nilai tukar dan inflasi dengan nilai tukar. Sedangkan hubungan tidak langsungnya adalah nilai tukar rupiah memediasi/tidak memediasi tingkat suku bunga dengan harga saham dan nilai tukar rupiah memediasi/tidak memediasi inflasi dan harga saham.

Tabel 61 Hasil Diagram Jalur

\begin{tabular}{lcrrrr}
\hline Hubungan variabel & $\begin{array}{l}\text { Original } \\
\text { Sample } \\
(\mathbf{O})\end{array}$ & $\begin{array}{l}\text { Sample } \\
\text { Mean } \\
(\mathbf{M})\end{array}$ & $\begin{array}{l}\text { Standard } \\
\text { Deviation } \\
\text { (STDEV) }\end{array}$ & $\begin{array}{l}\text { T Statistics } \\
(\mid \mathbf{O} / \text { STDEV })\end{array}$ & $\begin{array}{l}\text { P } \\
\text { Values }\end{array}$ \\
\hline $\begin{array}{l}\text { Tingkat Suku Bunga -> Harga } \\
\text { Saham }\end{array}$ & $-0,739$ & $-0,736$ & 0,068 & 10,922 & 0,000 \\
\hline Inflasi -> Harga Saham & $-0,023$ & $-0,029$ & 0,072 & 0,322 & 0,747 \\
\hline Nilai Tukar -> Harga Saham & 0,160 & 0,161 & 0,064 & 2,488 & 0,013 \\
& & & & &
\end{tabular}




\begin{tabular}{lccccc}
\hline $\begin{array}{l}\text { Tingkat Suku Bunga -> Nilai } \\
\text { Tukar }\end{array}$ & $-0,423$ & $-0,423$ & 0,093 & 4,532 & 0,000 \\
\hline Inflasi -> Nilai Tukar & $-0,113$ & $-0,112$ & 0,104 & 1,082 & 0,280 \\
\hline $\begin{array}{l}\text { Tingkat Suku Bunga -> Nilai } \\
\text { Tukar -> Harga Saham }\end{array}$ & $-0,068$ & $-0,072$ & 0,039 & 1,748 & 0,081 \\
\hline $\begin{array}{l}\text { Inflasi -> Nilai Tukar -> Harga } \\
\text { Saham }\end{array}$ & $-0,018$ & $-0,016$ & 0,017 & 1,095 & 0,274 \\
\hline
\end{tabular}

Sumber: Output PLS, 2019

Hasil pengujian pada Tabel 7 digunakan untuk menguji hipotesis yang ada. Hipotesis pertama menyatakan bahwa tingkat suku bunga berpengaruh terhadap harga saham. Hasil pengujian menunjukkan variabel tingkat suku bunga memiliki nilai T-statistik sebesar 10,922 dan p-value sebesar 0,000, sedangkan t-tabel sebesar 1,969 dan p-value kurang dari 0,05 atau 5\%. Dan original sample sebesar $-0,739$. Hasil pengujian menunjukkan bahwa nilai T-statistik $(10,922)>\mathrm{t}$-tabel $(1,969)$ dan $p$-value $(0,000<0,05$ serta original sample bernilai negatif. Hal tersebut menunjukkan bahwa variabel tingkat suku bunga secara langsung berpengaruh signifikan dengan arah negatif terhadap harga saham atau dengan kata lain $\mathrm{H} 1$ diterima. Hal ini berarti jika tingkat suku bunga mengalami kenaikan, maka harga saham akan mengalami penurunan.

Hipotesis kedua menyatakan bahwa inflasi berpengaruh terhadap harga saham. Hasil pengujian menunjukkan variabel inflasi memiliki nilai T-statistik sebesar 0,322 dan $p$-value sebesar 0,747, sedangkan t-tabel sebesar 1,969 dan $p$-value kurang dari 0,05 atau $5 \%$. Dan original sample sebesar -0,023. Hasil pengujian menunjukkan bahwa nilai Tstatistik $(0,322)<\mathrm{t}$-tabel $(1,969)$ dan $p$-value $(0,747)>0,05$ serta original sample bernilai negatif. Hal tersebut menunjukkan bahwa variabel inflasi secara langsung tidak berpengaruh signifikan dengan arah negatif terhadap harga saham atau dengan kata lain $\mathrm{H} 2$ ditolak. Hal ini berarti jika jika inflasi mengalami kenaikan, maka harga saham akan tetap.

Hipotesis ketiga menyatakan bahwa nilai tukar rupiah berpengaruh terhadap harga saham. Hasil pengujian menunjukkan variabel nilai tukar rupiah memiliki nilai T-statistik sebesar 2,488 dan p-value sebesar 0,013, sedangkan t-tabel sebesar 1,969 dan p-value kurang dari 0,05 atau 5\%. Dan original sample sebesar 0,160. Hasil pengujian menunjukkan bahwa nilai T-statistik $(2,488)>\mathrm{t}$-tabel $(1,969)$ dan $p$-value $(0,013)<0,05$ serta original sample bernilai positif. Hal tersebut menunjukkan bahwa variabel nilai tukar rupiah secara langsung berpengaruh signifikan dengan arah positif terhadap harga saham atau dengan kata lain H3 diterima. Hal ini berarti jika tingkat suku bunga mengalami kenaikan, maka harga saham akan mengalami kenaikan pula.

Hipotesis keempat menyatakan bahwa tingkat suku bunga berpengaruh terhadap nilai tukar rupiah. Hasil pengujian menunjukkan variabel tingkat suku bunga memiliki nilai T-statistik sebesar 4,532 dan $p$-value sebesar 0,000, sedangkan t-tabel sebesar 1,969 dan p-value kurang dari 0,05 atau 5\%. Dan original sample sebesar -0,423. Hasil pengujian menunjukkan bahwa nilai T-statistik $(4,532)>\mathrm{t}$-tabel $(1,969)$ dan $p$-value $(0,000)<0,05$ serta original sample bernilai negatif. Hal tersebut menunjukkan bahwa variabel tingkat suku bunga secara langsung berpengaruh signifikan dengan arah negatif terhadap nilai tukar rupiah atau dengan kata lain $\mathrm{H} 4$ diterima. Hal ini berarti jika tingkat suku bunga mengalami kenaikan, maka nilai tukar rupiah akan mengalami penurunan. 
Hipotesis kelima menyatakan bahwa inflasi berpengaruh terhadap nilai tukar rupiah. Hasil pengujian menunjukkan variabel inflasi memiliki nilai T-statistik sebesar 1,082 dan $p$-value sebesar 0,280, sedangkan t-tabel sebesar 1,969 dan $p$-value kurang dari 0,05 atau $5 \%$. Dan original sample sebesar $-0,113$. Hasil pengujian menunjukkan bahwa nilai T-statistik $(1,082)<\mathrm{t}$-tabel $(1,969)$ dan $p$-value $(0,280)>0,05$ serta original sample bernilai negatif. Hal tersebut menunjukkan bahwa variabel inflasi secara langsung tidak berpengaruh signifikan dengan arah negatif terhadap nilai tukar rupiah atau dengan kata lain H5 ditolak. Hal ini berarti jika inflasi mengalami kenaikan, maka nilai tukar rupiah akan tetap.

Hipotesis keenam menyatakan bahwa tingkat suku bunga berpengaruh terhadap harga saham yang dimediasi oleh nilai tukar rupiah. Hasil pengujian menunjukkan variabel tingkat suku bunga memiliki nilai T-statistik sebesar 1,748 dan p-value 0,081, sedangkan t-tabel sebesar 1,969 dan nilai $p$-value lebih dari 0,05 atau 5\%. Dan original sample sebesar -0,068. Hasil pengujian menunjukkan bahwa nilai T-statistik $(1,748)<\mathrm{t}-$ tabel dan $p$-value $(0,081)>0,05$ serta original sample bernilai negatif. Hal tersebut menunjukkan bahwa variabel tingkat suku bunga secara tidak langsung berpengaruh dengan arah negatif dan tidak signifikan terhadap harga saham yang dimediasi oleh nilai tukar rupiah atau dengan kata lain H6 ditolak. Hal ini berarti variabel nilai tukar rupiah tidak memediasi pengaruh tingkat suku bunga terhadap harga saham. Hal ini berarti bahwa semakin tinggi tingkat suku bunga yang diringi dengan semakin tinggi nilai tukar rupiah, maka tidak memiliki pengaruh terhadap harga saham.

Hipotesis ketujuh menyatakan bahwa inflasi berpengaruh terhadap harga saham yang dimediasi oleh nilai tukar rupiah. Hasil pengujian menunjukkan inflasi memiliki nilai T-statistik sebesar 1,095 dan p-value 0,274, sedangkan t-tabel sebesar 1,969 dan nilai $p$-value kurang dari 0,05 atau 5\%. Dan original sample sebesar -0,018. Hasil pengujian menunjukkan bahwa nilai T-statistik $(1,095)<\mathrm{t}$-tabel dan $p$-value $(0,274)>$ 0,05 serta original sample bernilai negatif. Hal tersebut menunjukkan bahwa variabel inflasi secara tidak langsung berpengaruh dengan arah negatif dan tidak signifikan terhadap harga saham yang dimediasi oleh nilai tukar rupiah atau dengan kata lain $\mathrm{H7}$ ditolak. Hal ini berarti variabel nilai tukar rupiah tidak memediasi pengaruh inflasi terhadap harga saham. Hal ini berarti bahwa semakin tinggi inflasi yang diringi dengan semakin tinggi nilai tukar rupiah, maka tidak memiliki pengaruh terhadap harga saham.

\section{SIMPULAN}

Berdasarkan hasil penelitian tingkat suku bunga, inflasi, dan nilai tukar rupiah terhadap harga saham perusahaan pada Jakarta Islamic Index yang terdaftar di Bursa Efek Indonesia bulan Januari 2014-Desember 2018 diperoleh kesimpulan bahwa:

Tingkat suku bunga berpengaruh negatif dan signifikan terhadap harga saham pada perusahaan yang terdaftar di Jakarta Islamic Index yang terdaftar di Bursa Efek Indonesia periode 2014-2018. Inflasi berpengaruh negatif namun tidak signifikan terhadap harga saham pada perusahaan yang terdaftar di Jakarta Islamic Index yang terdaftar di Bursa Efek Indonesia periode 2014-2018. Nilai tukar rupiah berpengaruh positif dan signifikan terhadap harga saham pada perusahaan yang terdaftar di Jakarta Islamic Index yang terdaftar di Bursa Efek Indonesia periode 2014-2018. Tingkat suku bunga berpengaruh negatif dan signifikan terhadap nilai tukar rupiah. Inflasi berpengaruh negatif dan tidak 
signifikan terhadap nilai tukar rupiah. Nilai tukar rupiah tidak memediasi pengaruh tingkat suku bunga terhadap harga saham pada perusahaan yang terdaftar di Jakarta Islamic Index yang terdaftar di Bursa Efek Indonesia periode 2014-2018. Nilai tukar rupiah tidak memediasi pengaruh inflasi terhadap harga saham pada perusahaan yang terdaftar di Jakarta Islamic Index yang terdaftar di Bursa Efek Indonesia periode 20142018.

Saran yang dapat diberikan dengan berdasarkan hasil penelitian adalah: Bagi penelitian selanjutnya diharapkan mempelajari referensi tentang faktor yang mempengaruhi harga saham seperti faktor internal yaitu harga saham, sedangkan faktor eksternal seperti tingkat suku bunga, inflasi, dan nilai tukar rupiah terhadap dollar (US) yang berarti tidak hanya bersumber pada hasil penelitian ini. Penelitian yang akan datang juga disarankan menambahkan rentang waktu yang lebih panjang sehingga nantinya diharapkan hasil yang diperoleh akan lebih dapat digeneralisasikan dan untuk memperluas penelitian serta menghasilkan analisis yang lebih baik.

\section{REFERENSI}

Abdullah, Thamrin., \& Tantri, Francis. (2012). Bank dan Lembaga Keuangan. Jakarta: RajaGrafindo Persada.

Achmad, Noor dan Liana, (2012). Pengaruh Suku Bunga SBI dan Kurs Dollar Terhadap Harga Saham di BEI. Jurnal Ilmiah Ranggagading,12(2), 128-135.

Amperaningrum. Izzati, (2011). Pengaruh Tingkat Suku Bunga SBI, Nilai Tukar Mata Uang dan Tingkat Inflasi Terhadap Perubahan Harga Saham. Jurnal Ekonomi, $4,160-164$.

An-Nisbah., 2017. (2017). Kontribusi Inflasi, Suku Bunga, Kurs, Produk Domestic Bruto Terhadap Harga Saham Kelompok Jakarta Islamix Index di Indonesia Periode 2007-2015. An-Nisbah, 4(1).

Aprilia, Annisa. (2017). "Pengaruh Inflasi, Tingkat Suku Bunga, dan Nilai Tukar terhadap Harga Saham Perusahaan Telekomunikasi di Bursa Efek Indonesia". Skripsi. Fakultas Ekonomi dan Bisnis Universitas Muhammadiyah Palembang.

Astuti, Ria., \& Apriani, E.P. (2013). Analisis Pengaruh Tingkat Suku Bunga (SBI), Nilai Tukar (KURS) Rupiah, Inflasi, Dan Indeks Bursa Internasional Terhadap IHSG. Diponegoro Journal Of Social And Politic Of Science, 1-8.

Efni, Yulia. (2009). "Pengaruh Suku Bunga Deposito, SBI, Kurs, dan Inflasi terhadap Harga Saham Perusahaan Real Estate dan Property di BEI”. Skripsi. Fakultas Ekonomi Universitas Riau.

Ginting, Maria Ratna Marisa., Topowijoyono, \& Sulasmiyati. Sri. (2016). Pengaruh Tingkat Suku Bunga, Nilai Tukar dan Inflasi terhadap Harga Saham. Jurnal Administrasi Bisnis (JAB), 35(2).

Hadi, Nor. (2013). Pasar Modal: Acuan Teoretis dan Praktis Investasi di Instrumen Keuangan Pasar Modal. Yogyakarta: Graha Ilmu.

Hermaniar, Nurul Fajar., (2013). "Pengaruh Pertumbuhan PDB, Tingkat Inflasi, dan Tingkat Suku Bunga terhadap Volatilitas Harga Saham Syariah dengan Nilai Tukar sebagai Variabel Intervening”. Skripsi. Fakultas Pendidikan Ekonomi dan Bisnis Universitas Pendidikan Indonesia.

Jayanti, Yusnita., Darminto, \& Sudjana, Nengah. (2014). Pengaruh Tingkat Inflasi, 
Tingkat Suku Bunga SBI, dan Indeks KLSE terhadap IHSG. Jurnal Administrasi Bisnis (JAB), 11(1).

Kewal, Suramaya, Suci. (2012). Pengaruh Inflasi, Suku Bunga, Kurs, dan Pertumbuhan PDB Terhadap Indeks Harga Saham Gabungan. Jurnal Economia, 8(1), 53-64.

Khajjah, Minkhatul. (2015). "Pengaruh Tingkat Inflasi dan Suku Bunga SBI terhadap Nilai Tukar". Skripsi. Fakultas Ekonomi Universitas Negeri Semarang.

Khalwaty, Tajul., (2000). Inflasi dan Solusinya. Cetakan Pertama. Jakarta: Gramedia Pustaka.

Kirana, Melinda Puspita Ayu., (2017). Pengaruh Tingkat Suku Bunga SBI terhadap Nilai Tukar Rupiah. Jurnal Equilibrium, 5(1).

Mamoed, Lettyshia., (2017). "Pengaruh Tingkat Inflasi, Nilai Tukar Kurs Dollar AS (USD) dan Tingkat Suku Bunga SBI terhadap Harga Saham Perusahaan PT. Bumi Serpong Damai Tbk yang Tercatat di Bursa Efek Indonesia”. Skripsi. Fakultas Ekonomi dan Bisnis Universitas Palangka Raya.

Mashrafiyah., (2017). Pengaruh Faktor Fundamental dan Teknikal terhadap Harga Saham Industri Perhotelan yang Terdaftar di Bursa Efek Indonesia. Jurnal Ekonomi, Keuangan dan Perbankan Syariah, 1(1), 116-131.

Martalena., Malinda, Maya. (2011). Pengantar Pasar Modal. Andi. Yogyakarta.

Martono,. 2004. Bank dan Lembaga Keuangan Lain. Cetakan Ketiga. Edisi Pertama. Yogyakarta: Ekonisia.

Musyaffa', Syabiq Arfidan., \& Sulasmiyati, Sri. (2017). Pengaruh Jumlah Uang Beredar, Inflasi dan Suku Bunga terhadap Nilai Tukar Rupiah terhadap Dolar. Jurnal Administrasi Bisnis (JAB), 50(4).

Nofiatin, Ike. (2013). Hubungan Inflasi, Suku Bunga, Produk Domestik Bruto, Nilai Tukar, Jumlah Uang Beredar, Dan Indeks Harga Saham Gabungan. Jurnal Aplikasi Manajemen, 11(2), 215-222.

Novitasari, Rani., (2018). "Pengaruh Profitabilitas dan Leverage terhadap Nilai Perusahaan dengan Kebijakan Dividen sebagai Variabel Intervening”. Skripsi. Fakultas Ekonomi Universitas Islam Negeri Maulana Malik Ibrahim Malang.

Puspitaningrum, Roshinta., Suhadak, \& Zahroh. (2014). Pengaruh Inflasi, Tingkat Suku Bunga SBI, dan Pertumbuhan Ekonomi Terhadap Nilai Tukar Rupiah Studi Pada Bank Indonesia Periode Tahun 2003-2012. Jurnal Administrasi Bisnis, 8(1).

Sambelay, J.J., Van Rate, Paulina, \& Baramuli, Dedy N. (2017). Analisis Pengaruh Profitabilitas terhadap Harga Saham pada Perusahaan yang Terdaftar di LQ45 Periode 2012-2016. Jurnal EMBA, 5(2), 753-761.

Wahyuningsih, Elvinia., Andini, Rita, \& Suprijanto, Agus. (2018). Pengaruh Tingkat Suku Bunga dan Inflasi terhadap Return Saham dengan Nilai Tukar Rupiah sebagai Variabel Intervening. Journal Of Accounting.

Zulelli, Rina., \& Wulan Sari, Yuniar. (2013). Pengaruh Tingkat Keuntungan Pasar,

Nilai Tukar Rupiah, Inflasi, dan Tingkat Suku Bung terhadap Return Saham

Industri Food and Beverage. Jurnal Wawasan Manajemen. 1(1).

www.bi.go.id

www.bps.go.id

www.idx.co.id

www.kompas.com

www.liputan6.com 